\title{
REVIEW AND COMPARATIVE ANALYSIS OF COMPLEX DIGITAL ELECTRICAL METERING DEVICES USED ON MODERN MERCHANT FLEET
}

\author{
Gurov K. A. ${ }^{1}$, Savolova E. V. ${ }^{2}$, Yarmolovych V. Y. ${ }^{3}$, Ezerovych D. M. ${ }^{4}$ \\ ${ }^{1}$ Компания NedaMaritimeAgencyCo, Греція \\ ${ }^{2,3}$ Одеський національний політехнічний університет, Одеса, Україна \\ ${ }^{4}$ Одеський національний університет ім. I.I. Мечникова, Одеса, Україна \\ ORCID: ${ }^{1}$ https://orcid.org/0000-0003-2598-3229, ${ }^{2}$ https://orcid.org/0000-0001-9266-9323, \\ ${ }^{3} \mathrm{https} / / /$ orcid.org/0000-0002-0708-2972, ${ }^{4} \mathrm{https}: / /$ orcid.org/0000-0003-0368-2089 \\ E-mail: ${ }^{1}$ guroffkonstantin@ gmail.com, ${ }^{2}$ elvira.onaxt@ gmail.com, ${ }^{3}$ vyy0147@ gmail.com, ${ }^{4}$ dme85928@ gmail.com
}

Copyright (C) 2020 by author and the journal "Automation of technological and business - processes".

This work is licensed under the Creative Commons Attribution International License (CC BY).

http://creativecommons.org/licanses/by/4.0

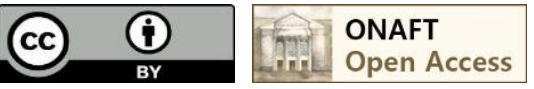

DOI: https://doi.org/10.15673/atbp.v12i2.1806

\begin{abstract}
Анотація. Для моніторингу та оптимізації роботи торгівельних суден створюється віддалений доступ до систем корабля, так званих мереж «судно-берег». Це вимагає використання нових комплексних циирових приладів. Вибір правильного і оптимального пристрою з доступних на сучасному ринку - завдання не з легких. У изій статті представлений огляд типових аналізаторів електричних величин, використовуваних для створення онлайн систем збору $і$ передачі даних. Порівняльний огляд трьох пристроїв різних виробників, які в даний час широко використовуються (Phoеnix Contact, Німеччина; ABB, Швейцарія; DEIF, Данія). Переглянуті дані складаються в таблицю. Наведено приклади використання изи пристроїв на конкретних суднах.

Для моніторингу та оптимізації роботи торгівельних суден встановлюється віддалений доступ до суднових систем, так званих мереж «судно-берег». Це вимагає використання нових складних иифррових електричних вимірювальних приладів. Вибір правильного та оптимального пристрою з доступних на поточному ринку не є легким завданням. У иій статті подано огляд типових аналізаторів електричних значень, які використовуються для створення онлайн-систем збору та передачі даних. Представлено порівняльний огляд трьох пристроїв, які в даний час широко використовуються різними виробниками (Phoепіх Contact, Німеччина; АВВ, Швейцарія; DEIF, Данія). Переглянуті дані складаються в таблицю. Наведено приклади використання ичих пристроїв на конкретних суднах.

Abstract. To monitoring and optimization the operation of merchant vessels, remote access to the ship's systems, the socalled "ship-shore" networks, is being established. This requires the use of new complex digital electrical metering devices. Choosing the right and optimal device from the available on the current market is not an easy task. This article provides an overview of the typical electrical value analyzers used to create online data collection and transmission systems. A comparative review of the three devices currently widely used by different manufacturers (Phoenix Contact, Germany; ABB, Switzerland; DEIF, Denmark). The data reviewed is compiled into a table. Examples of the usage of these devices on specific vessels are given.
\end{abstract}

Ключові слова: аналізатор, лічильник енергії, мережі, торговий флот, інтерфейс, дистанційне управління, точність, модулі зв'язку, вимірювання, дані.

Keywords: analyzer, energy meter, networks, merchant fleet, interface, remote control, accuracy, communication modules, measurements, data.

\section{Introduction}

At the moment, multiple electrical parameters analyzers are widely introduced - digital devices that allow not only to fix parameters, but also to transmit information about the measured signals, creating a network of remote control. This replacement saves space and money, as one device is installed instead of the n-quantity (A, V, W, Hz, cos $\Phi$, etc.). It also solves the task of implementing an online data collection and transmission system. 


\section{The purpose of the work}

In this article, we want to talk about some of these devices successfully implemented on merchant fleet (especially three sister-ships (Tsuneishi Shipbuilding Co., Ltd. Shipyard Ship No’s: SS197, SS198; Namura Shipbuilding Co., Ltd. Shipyard Ship No: S414)).

Here's an overview of three standard complex digital electrical metering devices:

1. The EEM-MA600 (maker Phoenix Contact, Deutschland) is a highly accurate energy meter for measuring electrical parameters in low voltage installations up to $700 \mathrm{~V}$. It is designed for front-panel installation and supports the measurement, counting, and display of all electrical parameters in 1, 2, and 3-phase networks with and without neutral conductors (symmetrical and asymmetrical). The buttons located on the front of the device allow fast, direct access to the required parameters as well as device configuration. The device can be expanded using the special function and communication modules and can be configured using communication modules (Ethernet, PROFIBUS, MODBUS). The device can also be used to record the total harmonic distortion (THD) of the currents and voltages as well as the content of individual harmonic (odd) vibrations. Values up to the $25^{\text {th }}$ harmonic can be shown on the display. The display up to the $63^{\text {rd }}$ harmonic is possible via the MODBUS registers. A trend calculation can be performed for the real and reactive power, and alarm management can be activated (extension module EEM-2DIO-MA600 required) [1].

The following parameters can be measured or monitored:

Current:

- actual values I1, I2, I3, IN; average value/maximum value I1, I2, I3, IN; harmonic content and content of individual odd harmonics (displays up to $25^{\text {th }}$ ).

Voltages:

- actual phase/phase value (U12, U23, U31); actual phase/N value (V1, V2, V3); average value/maximum value for phase/phase (U12, U23, U31) and phase/N (V1, V2, V3); harmonic content and content of individual odd harmonics (displays up to $25^{\text {th }}$ ).

Frequency.

Real, reactive and apparent power:

- actual value for each phase (P1, P2, P3, Q1, Q2, Q3, S1, S2, S3); total actual value ( $\Sigma$ P, $\Sigma$ Q, $\Sigma$ S); average value/maximum value ( $\Sigma \mathrm{P}, \Sigma \mathrm{Q}, \Sigma \mathrm{S})$; trend ( $\Sigma \mathrm{PPR}, \Sigma \mathrm{QPR}, \Sigma \mathrm{SPR})$.

Power factor:

- actual value for each phase (PF1, PF2, PF3); total actual value ( $\mathrm{PF})$; average value/maximum value ( $\mathrm{PPF})$.

Energy (power meter):

- real energy $(\mathrm{EA}+/-)$; reactive energy $(\mathrm{ER}+/-)$; apparent energy $(\mathrm{ES})$.

Harmonics:

- total harmonic distortion of currents I1, I2, I3, IN; total harmonic distortion of line voltage U12, U23, U31; total harmonic distortion of line voltage against $\mathrm{N} \mathrm{V1,} \mathrm{V2,} \mathrm{V3;} \mathrm{individual} \mathrm{harmonic} \mathrm{content} \mathrm{up} \mathrm{to} 63^{\mathrm{rd}}$.

For currents I1, I2, I3.

For line voltages (U12, U23, U31).

For line voltages against N (V1, V2, V3).

Temperatures:

- internal; external via 3 PT100 temperature sensors.

Alarm setting:

- for all parameters (extension module EEM-2DIO-MA600 required).

Displaying measured values:

$\mathrm{I} /{ }^{\circ} \mathrm{C}$ button:

- currents (I1, I2, I3, IN), real energy (EA); currents (I1, I2, I3, IN), average value (I), real energy (EA); temperatures (when extension module EEM-TEMP-MA600 is connected).

U/F button:

- line voltages (U12, U23, U31), frequency (F), real energy (EA); line voltages against N (V1, V2, V3), frequency (F), real energy (EA); line voltages (U12, U23, U31), average value (U), real energy (EA); line voltages against N (V1, V2, V3), average value $(\mathrm{V})$, real energy $(\mathrm{EA})$.

P/PF button:

- real power for each phase (P1, P2, P3), total real power $(\Sigma \mathrm{P})$, real energy $(\mathrm{EA})$; reactive power for each phase $(\mathrm{Q} 1, \mathrm{Q} 2$, $\mathrm{Q} 3)$, total reactive power $(\Sigma \mathrm{Q})$, real energy (EA); apparent power for each phase (S1, S2, S3), total apparent power ( $\Sigma \mathrm{S})$, real energy (EA); power factor for each phase (PF1, PF2, PF3), total power factor ( $\Sigma \mathrm{PF})$, real energy (EA); real power trend $(\Sigma \mathrm{PPR})$; reactive power trend ( $\Sigma \mathrm{QPR})$; apparent power trend $(\Sigma \mathrm{SPR})$.

MAX/AVG button:

- average value/maximum value for currents (I1, I2, I3, IN), real energy (EA); average value/maximum value for line voltages phase/phase (U12, U23, U31), average frequency value (F), real energy (EA); average value/maximum value for line voltages phase/N (V1, V2, V3), average frequency value (F), real energy (EA); average value/maximum real power value $(\Sigma \mathrm{P})$; average value/maximum reactive power value $(\Sigma \mathrm{Q})$; average value/maximum apparent power value $(\Sigma \mathrm{S})$.

H button: 
- total harmonic distortion of currents (THD I1, THD I2, THD I3, THD IN), real energy (EA); total harmonic distortion of phase/phase (THD U12, THD U23, THD U31) conductor voltages, real energy (EA); total harmonic distortion of phase/N (THD V1, THD V2, THD V3) conductor voltages, real energy (EA); harmonic content for currents (I1, I2, I3, IN), real energy (EA); harmonic content for conductor voltages L/L (U12, U23, U31), real energy (EA); harmonic content for line voltages L/N (V1, V2, V3), real energy (EA).

E button:

- positive real energy $(\mathrm{EA}+)$; positive reactive energy $(\mathrm{ER}+)$; apparent energy $(\mathrm{ES})$; negative real energy (EA-); negative reactive energy (ER-); operating hours.

2. The M2M (maker ABB, Switherland) network analyser is an instrument that measures of the main electric quantities on 3-phase and monophase networks designed for the monitoring and the local or remote analysis of: electrical parameters of systems in low or medium voltage and system energy consumption [2].

All of the M2M series models are able to measure and process the quantities shown below:

- voltages (phase neutral and concatenated) and relative peak values;

- currents and relative peak values;

- power factors or PF phases and the 3-phase system, with distinction iconbetween the inductive and capacitive load;

- frequency (measured on L1-N phase);

- active, reactive and apparent phase energies and the 3-phase system on 2quadrants (with automatic recognition function of the AT directions);

- active, reactive and apparent power phases and the 3-phase system on 4quadrants (monitoring of energy aborbed and generated by the system);

- average power values on a time period programmed by the user;

- maximum calculated demand on active and apparent power;

- voltage and current THdF expressed in absolute and percent values;

- T1 increase total operating hour counter and T2 decrease partial hour counter;

- balance of active, reactive and apparent energy of 3-phase system,balance = absorbed energy - generated energy;

- balance of the "partial" active, reactive and apparent energies of the 3-phase system on 4 quadrants in a period that can be programmed by the user, balance = energy absorbed - energy generated;

All of the models have the following in common:

- multivoltage supply voltage;

- multilanguage display with scrolling text;

- self-diagnostic function for the installation control;

- setting of a safety password;

- T1 and T2 hour counter.

3. The MIC (maker DEIF, Denmark) multi-instrument is a microprocessor-based measuring unit providing measurement of all electrical quantities on a 1 or 3-phase electric energy distribution network. The measurements are shown on the built-in display. The MIC also has an RS485 interface that supports data exchange with a control system via Modbus RTU protocol. The MIC measures true RMS values on all 1 or 3-phase network topologies with or without neutral and with both balanced and unbalanced load. The MIC can replace a large number of standard analogue instruments in all electrical measuring applications. It can be applied both as a regular instrument and as a remote value-reading and control unit transmitting all measured values to the remote control system via the serial interface. The MIC contains all necessary measuring circuits and presents all values on a display with blue backlight. The display has 4 digits resolution for all measurements with the exception of the energy counter ( 9 digits). The backlight "on-time" is selectable. The MIC is a flexible measuring unit that enables the user to easily adapt the instrument to the individual application. Counter reset and change of the instrument settings can be password protected [3].

Measured and calculated values:

Voltage (phase-neutral):

-actual voltage of each phase and average voltage.

Voltage (phase to phase):

-actual voltage of each line and average voltage.

Current:

- actual current of each phase, average current and neutral current.

Active power:

- actual active power of each phase and total power.

Reactive power:

- actual reactive power of each phase and total reactive power.

Apparent power:

- actual apparent power of each phase and total apparent power.

Power factor:

- actual power factor of each phase and system average power factor.

Frequency:

- actual frequency of L1. 
Power quality:

- voltage/current unbalance factor, total harmonics distortion of voltage/current of each phase and total harmonics distortion of average voltage/current.

Energy counter:

- the MIC has 8 counters: export/import kWh, export/import kVArh, absolute sum of export/import kWh, algebraic sum of export/import kWh, absolute sum of export/import kVArh, algebraic sum of export/import kVArh.

Statistics data:

- max/min values of voltage, current, total power, total reactive power, total apparent power, power demand, power factor and frequency.

Running hour:

- meters the duration of the operation.

Real time clock:

- date and time.

The appearance of the devices is shown in Figure 1.

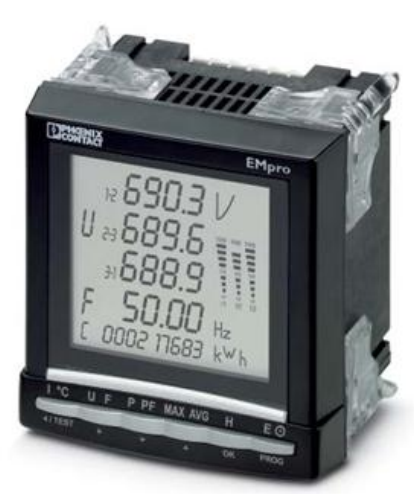

a)

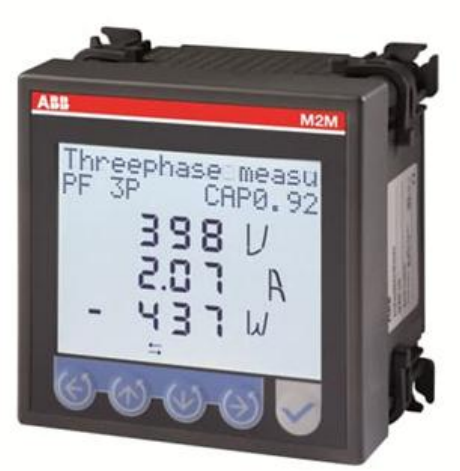

b)

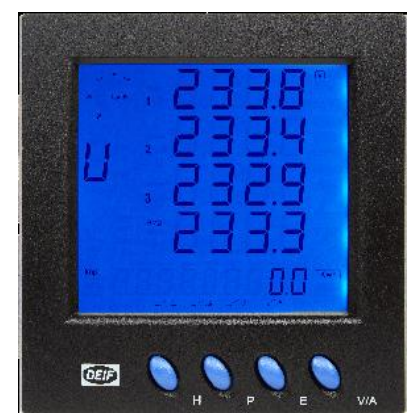

c)

Figure 1 - a) EEM-MA600, Phoenix Contact; b) M2M, ABB; c) MIC, DEIF;

The specifications of these devices can be presented as a composite table (Table 1).

Table 1 - The specifications of these devices

\begin{tabular}{|c|c|c|c|}
\hline & $\begin{array}{c}\text { EEM-MA600 (Phoenix } \\
\text { Contact) }\end{array}$ & M2M (ABB) & MIC (Deif A/S) \\
\hline 1 & 2 & 3 & 4 \\
\hline $\begin{array}{c}\text { Supply } \\
\text { Supply voltage range } \\
\text { Nominal power consumption }\end{array}$ & $\begin{array}{c}110 \ldots 400 \mathrm{VAC} \pm 10 \% \\
120 \ldots 350 \mathrm{VDC} \pm 20 \% \\
<10 \mathrm{VA} \text { (without extension } \\
\text { modules) } \\
<20 \mathrm{VA} \text { (with extension } \\
\text { modules) }\end{array}$ & $\begin{array}{c}\text { 24..240VAC/VDC } \\
\text { 7VA (max) }\end{array}$ & $\begin{array}{c}85 \ldots 264 \mathrm{VAC} \\
50 / 60 \mathrm{~Hz} \ldots 48 / 100 \ldots 280 \mathrm{~V} \\
\text { DC } \\
\leq 2 \mathrm{VA}\end{array}$ \\
\hline $\begin{array}{c}\text { Dimension W/H/D } \\
\text { Installation depth } \\
\text { Weight }\end{array}$ & $\begin{array}{c}96 \times 96 \times 82 \mathrm{~mm} \\
60-80 \mathrm{~mm} \\
400 \mathrm{~g}\end{array}$ & $\begin{array}{c}96 \times 96 \times 77 \mathrm{~mm} \\
57 \mathrm{~mm} \\
400 \mathrm{~g}\end{array}$ & $\begin{array}{c}92 \times 92 \times 78 \mathrm{~mm} \\
64 \mathrm{~mm} \\
350 \mathrm{~g}\end{array}$ \\
\hline $\begin{array}{l}\text { Voltage measurement } \\
\text { Input voltage range } \\
\text { Accuracy }\end{array}$ & $\begin{array}{c}\text { 18...700VAC phase/phase } \\
11 \ldots 404 \mathrm{VAC} \\
\text { phase/neutral } \\
0,20 \%\end{array}$ & $\begin{array}{c}10 \ldots 500 \mathrm{VAC} \\
\text { phase/neutral } \\
0,50 \%\end{array}$ & $\begin{array}{c}\text { 10...480VAC phase/phase } \\
\text { up to } 230 \mathrm{VAC} \\
\text { phase/neutral } \\
0,20 \%\end{array}$ \\
\hline
\end{tabular}


Table 1 (continuation)

\begin{tabular}{|c|c|c|c|}
\hline 1 & 2 & 3 & 4 \\
\hline $\begin{array}{c}\text { Current measurement } \\
\text { Input current (via external } \\
\text { transformer) } \\
\text { Overload capacity } \\
\text { Accuracy }\end{array}$ & $\begin{array}{c}\leq 9999 \text { A primary } \\
\text { 1A or } 5 \text { A secondary } \\
\text { 10A (continuous) } \\
0,20 \%\end{array}$ & $\begin{array}{c}1 \ldots 10000 \mathrm{~A} \text { primary } \\
50 \mathrm{~mA} \ldots 5 \mathrm{~A} \text { secondary } \\
10 \mathrm{~A} \text { (continuous) } \\
0,50 \%\end{array}$ & $\begin{array}{c}1 \mathrm{~A} \text { or } 5 \mathrm{~A} \\
10 \mathrm{~A} \text { (continuous) / 100A } \\
(1 \mathrm{sec}) \\
0,20 \%\end{array}$ \\
\hline $\begin{array}{l}\text { Power measurement } \\
\text { Measuring range } \\
\text { Accuracy } \\
\text { Real energy } \\
\text { Reactive energy }\end{array}$ & $\begin{array}{c}0 \ldots 8000 \mathrm{MW} / \mathrm{Mvar} / \mathrm{MVA} \\
0,50 \% \\
\text { Class 0.5S (IEC 62053-22) } \\
\text { Class } 2 \text { (IEC 62053-23) }\end{array}$ & $\begin{array}{c}\text { 0...10GWh/Varh/Vah } \\
\text { single phase } \\
0 \ldots 30 \mathrm{GWh} / \text { Varh/Vah 3- } \\
\text { phase } \\
1 \% \\
\text { Class 1(IEC 62053-23) }\end{array}$ & $\begin{array}{c}\text { 0..10000MW/Mvar/MVA } \\
0,50 \% \\
\text { Class } 1(\mathrm{EN} \mathrm{61036)} \\
\text { Class } 2(\mathrm{EN} \mathrm{61268)}\end{array}$ \\
\hline $\begin{array}{c}\text { Input data } \\
\text { Measuring princple } \\
\text { Measured value }\end{array}$ & $\begin{array}{c}\text { True r.m.s. value } \\
\text { measurement (TRMS) } \\
\text { up to } 63 \mathrm{Harmonic} \\
\text { AC sine }(45 \mathrm{~Hz} . .65 \mathrm{~Hz})\end{array}$ & $\begin{array}{l}\text { Sampling TRMS } \\
\text { 45Hz...65Hz }\end{array}$ & $\begin{array}{c}\text { 3-phase TRMS } \\
\text { measurement } \\
45 \mathrm{~Hz} \ldots 65 \mathrm{~Hz}\end{array}$ \\
\hline Output data & $\begin{array}{c}\text { Optional for special } \\
\text { function/communication } \\
\text { module }\end{array}$ & $\begin{array}{c}2 \text { outputs programmable } \\
\text { with pulse or threshold } \\
\text { alarms }\end{array}$ & $\begin{array}{c}\text { RS485 serial output } \\
\text { Modbus RTU protocol. } \\
\text { Optional } 2 \text { digital } \\
\text { pulse/limit outputs }+ \\
\text { 2relays } \\
\end{array}$ \\
\hline $\begin{array}{c}\text { Electrical isolation } \\
\text { Rated insulation voltage } \\
\text { Test voltage }\end{array}$ & $\begin{array}{c}<300 \mathrm{VAC}(\mathrm{L} / \mathrm{N}) \text { surge V } \\
\text { category III } \\
\geq 300 \mathrm{VAC} . .600 \mathrm{VAC} \\
\text { surge V category II } \\
3,5 \mathrm{kVAC}(50 \mathrm{~Hz}, 1 \mathrm{~min}) \\
\text { safe isolation }\end{array}$ & $3,7 \mathrm{kVAC}(1 \mathrm{~min})$ & $\begin{array}{c}\text { EN 61010-1 category III } \\
2,2 \mathrm{kV}\end{array}$ \\
\hline $\begin{array}{c}\text { Connection data } \\
\text { Conductor cross section } \\
\text { (current) } \\
\text { Conductor cross section } \\
\text { (voltage and other) } \\
\text { Connection method } \\
\text { Tightening torque }\end{array}$ & $\begin{array}{c}0,5 \ldots 6 \mathrm{~mm} 2 \\
0,5 \ldots 2,5 \mathrm{~mm} 2 \\
\text { screw connection } \\
0,4 \mathrm{Nm}\end{array}$ & $\begin{array}{c}\text { up to } 6 \mathrm{~mm} 2 \\
\text { up to } 2,5 \mathrm{~mm} 2 \\
\text { screw connection } \\
0,4 \mathrm{Nm}\end{array}$ & $\begin{array}{l}\text { up to } 5 \mathrm{~mm} 2 \\
\text { pluggable block } \\
\quad 0,5 \mathrm{Nm}\end{array}$ \\
\hline $\begin{array}{c}\text { Ambient conditions } \\
\text { Ambient temperature } \\
\text { (operation) } \\
\text { Ambient temperature } \\
\text { (storage/transport) } \\
\text { Permissible humidity } \\
\text { (operation) }\end{array}$ & $\begin{array}{c}-10 \operatorname{deg} C \ldots+55 \operatorname{deg} C \\
(14 \operatorname{degF} \ldots 131 \operatorname{degF}) \\
-20 \operatorname{deg} C \ldots+85 \operatorname{deg} C \\
(-4 \operatorname{degF} \ldots 185 \operatorname{degF}) \\
\max 95 \%\end{array}$ & $\begin{array}{c}-5 \operatorname{deg} C \ldots+55 \operatorname{deg} C \\
(23 \operatorname{degF} \ldots 131 \mathrm{degF}) \\
-10 \operatorname{deg} C \ldots+60 \mathrm{deg} C \\
(14 \operatorname{degF} \ldots 140 \mathrm{degF}) \\
\max 93 \% \text { (without } \\
\text { condensation) at 40degC }\end{array}$ & $\begin{array}{c}-5 \operatorname{degC} \ldots+55 \operatorname{deg} C \\
(23 \operatorname{degF} \ldots 131 \operatorname{degF}) \\
-40 \operatorname{deg} C \ldots+70 \operatorname{deg} C \\
(-40 \operatorname{degF} \ldots 158 \operatorname{degF}) \\
\max 95 \% \text { (without } \\
\text { condensation) }\end{array}$ \\
\hline $\begin{array}{c}\text { Degree of protection } \\
\text { Frontal } \\
\text { At terminals }\end{array}$ & $\begin{array}{l}\text { IP } 52 \\
\text { IP } 30\end{array}$ & $\begin{array}{l}\text { IP } 50 \\
\text { IP } 25\end{array}$ & $\begin{array}{l}\text { IP } 40 \\
\text { IP } 20\end{array}$ \\
\hline Hour counters & + & + & + \\
\hline
\end{tabular}




\title{
Findings
}

Based on practical experience in the operation of ship's electrical systems, let's give examples of the specific use of the above devices. In particular, the energy meters EEM-MA600 (Phoenix Contact) were installed in online data acquisition system (DAQ Vector) to control parameters of all generator plants on board of motor vessel (bulk carrier, 2016 year build (Japan), deadweight $82000 \mathrm{mt}$ ). Chosen due to higher supply voltage (no need to install additional transformer), high level of electrical isolation and high accuracy class of measurements. The multi-instrument MIC (DEIF) used in power control board of Ballast Water Treatment System (TechCross) to control output energy loads from all electrolyzing units on board of motor vessels (bulk carriers, 2016 year build (China), deadweight 82000mt). Chosen due to RS485 interface that supports data exchange with a control system. The network analyzer M2M (ABB) commonly used in different kind of control boards of vessel machineries such as auxiliary composite boilers, steering gears, fuel and oil purifiers, etc. Due to smaller installation size and alarm outputs.

It should be noted that despite the successful introduction of digital integrated electrical metering devices, analog devices still do not lose their relevance. In particular, for local reading data that do not require further transmission of data to the remote control network, replacing all devices with digital analogues is not necessary.

\section{References}

[1] User manual for energy meter for single, two and three-phase networks UM EN EEM-MA600, published by PHOENIX CONTACT GmbH \& Co. KG Flachsmarktstraße 8, 32825 Bloomberg Deutschland. www.phoenixcontact.com

[2] Assembly and use instructions for network analyzer M2M (2CSG299883R4052), published by ABB SACE A division of ABB S.p.A. Vialedell'Industria 18, 20010 Vittuone (MI). www.abb.com

[3] Installation instructions and reference handbook for multi-instrument MIC (4189320009H), published by DEIF A/S, Frisenborgvej 33, DK-7800 Skive, Denmark. The serial interface manual, the data sheet and the free utility software. www.deif.com

\section{УДК 658.5}

\section{СТАН РОЗВИТКУ ТА ШЛЯХИ УДОСКОНАЛЕННЯ СИСТЕМ АВТОМАТИЧНОГО КЕРУВАННЯ ПАРАМЕТРАМИ ВИПРОМІНЮВАННЯ DFВ ЛАЗЕРІВ}

\author{
Похлєбіна Н.О. ${ }^{1}$, Мазур O.B. ${ }^{2}$, Kovalchuk D. ${ }^{3}$ \\ Одеська національна академія харчових технологій, Одеса, Україна \\ ORCID: ${ }^{1}$ https://orcid.org/0000-0002-9789-608X, ${ }^{2}$ https://orcid.org/0000-0001-7104-9010, \\ ${ }^{3}$ https://orcid.org/0000-0003-0549-5244 \\ E-mail: ${ }^{1}$ pohlebina.odessa@gmail.com, ${ }^{2}$ mazur.a.v.ua@gmail.com, ${ }^{3}$ radiolomaster@gmail.com
}

Copyright (C) 2020 by author and the journal "Automation of technological and business - processes". This work is licensed under the Creative Commons Attribution International License (CC BY). http://creativecommons.org/licanses/by/4.0

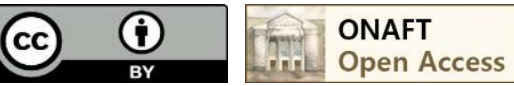

DOI: https://doi.org/10.15673/atbp.v12i2.1807

Анотація. Робота присвячена дослідженню напівпровідникових лазерів, їх функціонуванню, формалізації процесу як об'єкту керування. Розглянуті системи автоматичного керування напівпровідниковими лазерними діодами 3 розподіленим зворотнім зв'язком, зокрема одночастотні DFB- (англ. Distributed feedbacklaser «з розподіленим зворотним зв'язком»)лазерні діоди, які використовуються, як в якості високостабільних джерел оптичного сигналу у системах передачі даних так $і$ джерел випромінювання із змінною довжиною хвилі випромінювання. Приведені основні відомості про лазерні діоди, їх характеристики та класифікація за фізичним станом. Розглянуті питання використання DFB-лазерів в якості джерела когерентного електромагнітного випромінювання зі змінною довжиною хвилі випромінювання. Представлена структурна схема типового напівпровідникового лазерного DFВ-модуля, 3 взаємозв'язками між його основними компонентами. Проведена параметризація проиесу формування лазерного випромінювання до рівня параметричної схеми. Представлена параметрична схема прочесу як об'єкту керування та структурна схема моделі прочесу. Проведено аналіз структурної організація існуючих систем автоматичного 